\title{
The first record of Lutzomyia longipalpis (Lutz \& Neiva, 1912) (Diptera: Psychodidae: Phlebotominae) in the State of Paraná, Brazil
}

\author{
Demilson Rodrigues dos Santos ${ }^{[1]}$, Adão Celestino Ferreira ${ }^{[2]}$ and Alceu Bisetto Junior ${ }^{[3]}$
}

[1]. Núcleo de Entomologia de Maringá, 15a Regional de Saúde, Secretaria de Estado da Saúde do Paraná, Maringá, PR. [2]. Núcleo de Entomologia de Foz do lguaçu, 9å Regional de Saúde, Secretaria de Estado da Saúde do Paraná, Foz do Iguaçu, PR. [3]. Coordenação em Entomologia, Secretaria de Estado da Saúde do Paraná, Curitiba, PR.

\section{ABSTRACT}

Introduction: We report the first find of Lutzomyia longipalpis in the State of Paraná, Brazil. Methods: The specimens were captured in the urban area of the municipality of Foz do Iguaçu, with Falcão light traps, in domiciliary and peridomiciliary areas of 61 properties, on two consecutive nights from 18:00 to 06:00hs in March 2012. Results: We captured 40 specimens of Lu. longipalpis and 54 specimens of other sandfly species. Conclusions: This find expands knowledge of the geographical distribution of this sandfly in Brazil.

Keywords: Lutzomyia longipalpis. Sandfly. Paraná.

Lutzomyia longipalpis (Lutz \& Neiva) is the main vector of Leishmania chagasi (Cunha \& Chagas), the etiological agent of visceral leishmaniasis (VL) in the New World ${ }^{1}$. This severe chronic disease is widely distributed in Latin America, especially in Brazil, where it is endemic in large urban centers of the North, Northeast, Southeast and Midwest ${ }^{2}$. In southern Brazil, Lutzomyia longipalpis was first recorded in areas of occurrence of human and canine VL, in the City of São Borja, State of Rio Grande do Sul ${ }^{3}$. In this state, the canine disease had been diagnosed earlier, in Santa Maria City ${ }^{4}$. In the State of Paraná, human cases have been recorded in the rural area of Altônia municipality,

In Argentina, Uruguay and Paraguay, Lu. longipalpis has been reported in areas that coincide with the occurrence of $\mathrm{VL}^{7-9}$. In Argentina, where more studies on sandflies have been carried out, the geographical distribution of Lu. longipalpis includes several municipalities in the provinces of Corrientes, Entre Rios, Formosa and Misiones ${ }^{10-12}$. In Misiones, Lu. longipalpis was found in the urban area of Puerto Iguazú, on the border with the City of Foz do Iguaçu, Paraná11.

In 2004 and 2005, Silva et al, $2008^{13}$ did not detect Lu. longipalpis in 37 municipalities of Paraná, in areas vulnerable to the occurrence of LV. The species was also not found in over 39 other municipalities of this state, surveyed from 2006 through 2011 (DR Santos: unpublished data). In these two periods, sampling performed in the rural area of Foz do Iguaçu, in the localities Porto Franco, Cataratas late Club (on the border with Paraguay), Porto Meira, Parque Três Fronteiras and Pedreira São João (border with Argentina), resulted in the capture of the species Nyssomyia whitmani (Antunes \& Coutinho), Nyssomyia neivai (Pinto), Micropygomyia quinquefer (Dyar) and Psathyromyia shannoni (Dyar). The present contribution reports the first find of $L u$. longipalpis in the State of Paraná, and updates information on the sandfly fauna in the urban area of Foz do Iguaçu.

Address to: Demilson Rodrigues dos Santos. Lab. Entomologia de Maringá-PR/15åRS/ SESA/PR. Trav. Jeferson Wanderley Silva 718, Jardim Internorte, 87045-270 Maringá, PR, Brasil.

Phone: 5544 3229-1431.

e-mail: demilson.entomologia@ig.com.br

Received in 06/05/2012

Accepted in 14/08/2012
The municipality of Foz do Iguaçu (2532'45"S and 54이' $07^{\prime \prime} \mathrm{W}$ ) is located in western Paraná on the border of Brazil with Paraguay and Argentina (Figure 1) and has an area of $617.71 \mathrm{~km}^{2}$ and an estimated population of 256,081 inhabitants. The climate is humid subtropical, with hot summers, infrequent frosts, and rain in all months of the year. The maximum mean annual temperature is around $33^{\circ} \mathrm{C}$ and the minimum can fall below freezing. Annual rainfall varies around $1,800 \mathrm{~mm}$. The terrain consists of gently rolling slopes with deep clayey soils of eruptive origin, rich in organic matter. The vegetation in the National Park is subtropical, with lowland rainforest on the banks of the Paraná and Iguaçu rivers ${ }^{14}$.

The entomological survey was conducted from 19 to 29 March 2012, in 61 residential buildings of six urban localities of Foz do Iguaçu (Vila Carimã, Jardim Cataratas, Ponte Internacional Tancredo Neves, Jardim das Flores, Profilurb and Jardim Santa Rosa), which are geographically recognized by the National Dengue Control Program (Figure 1). In the first five locations (on the border with Argentina and Paraguay), 60 Falcão light traps were installed. In the Jardim Santa Rosa, about $10 \mathrm{~km}$ from the other locations, a trap was installed to assess the degree of dispersal of Lu. longipalpis in relation to the border among the three countries, since this sandfly was previously recorded on the other side of the Iguazú River in the City of Puerto Iguazú, Argentina ${ }^{11}$.

The sandflies were caught on properties characterized by the presence of dogs, chickens, pigs and other domestic animals, vegetation, moisture and organic matter accumulation in the soil of the peridomestic environment, which meet the sandflies' requirements for food (blood meals) and breeding. Traps were placed in porches of homes, domestic animal shelters (kennel, chicken coop and pigsty) and gardens, on two consecutive nights, from 18:00 to 06:00hs. After sorting, the sandflies were prepared, mounted and identified in the Laboratório of the Núcleo de Entomologia of Maringá, Paraná, where part of the specimens of Lu. longipalpis are deposited in the entomological collection. Species were identified according to Galati, $2003^{15}$ and confirmed by the Centro de Referência Nacional e Internacional para Flebotomíneos of the Laboratório de Leishmanioses, Centro de Pesquisas René Rachou, Fundação Oswaldo Cruz, Minas Gerais. 


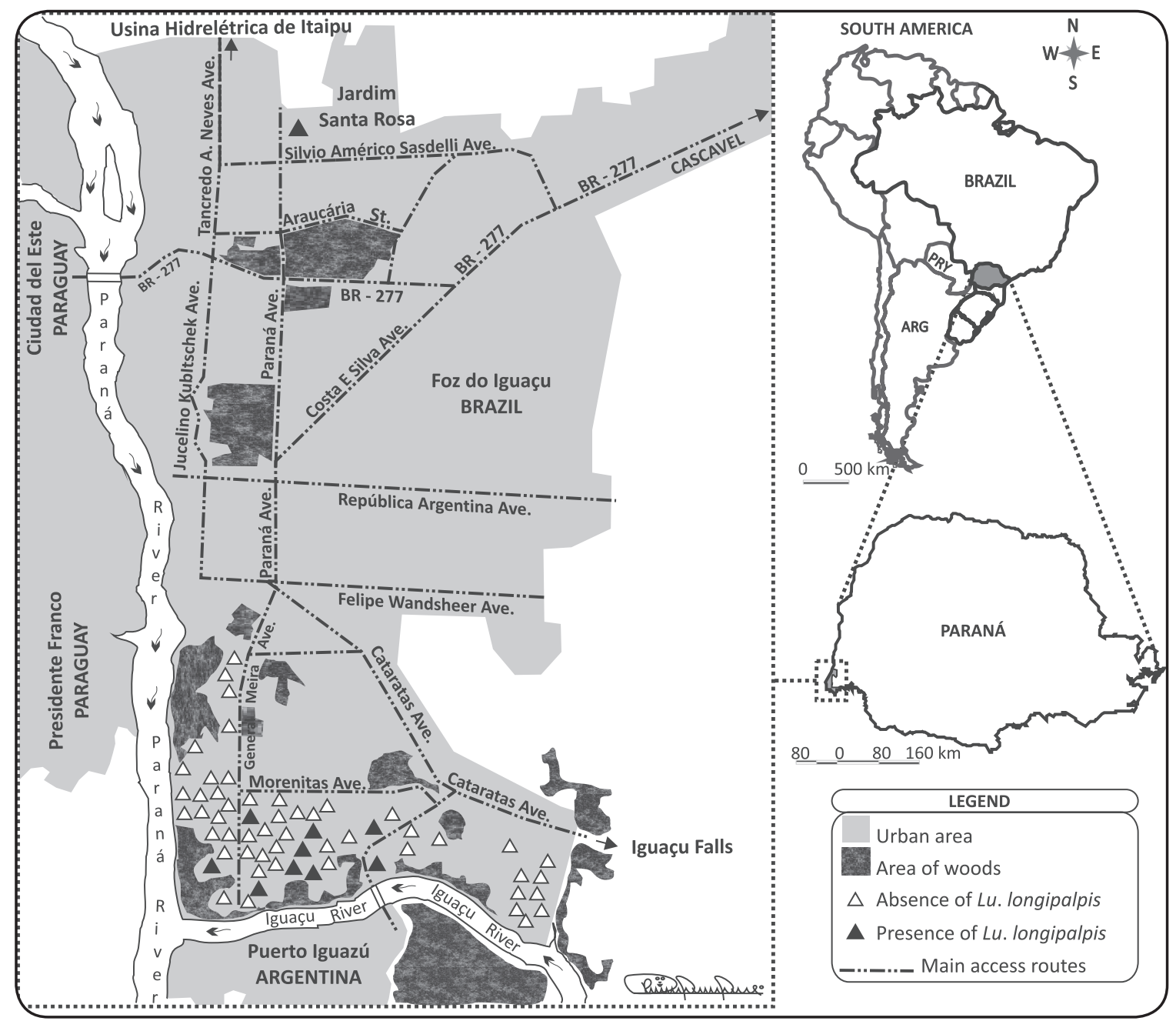

FIGURE 1 - Locations of phlebotomine collections in the urban area of Foz do Iguaçu, State of Paraná, Brazil.

We collected 40 specimens of Lu. longipalpis (30 males and 10 females), including 18 in kennels, 11 in chicken coops, six in residences, three in pigsties and two in gardens, distributed in ten buildings in all the localities except Vila Carimã. Together with Lu. longipalpis, 54 other phlebotomines were collected, representing the species Ny. whitmani, Mi. quinquefer, Brumptomyia brumpti (Larrousse), Migonemyia migonei (França), Pintomyia pessoai (Coutinho \& Barretto), Martinsmyia alphabetica (Fonseca) and Evandromyia cortelezzii (Brèthes), some of which have the potential to transmit cutaneous leishmaniasis agent.

The record of Lutzomyia longipalpis in Paraná contributes to knowledge of the geographical distribution of vectors of Leishamnia chagasi in Brazil, suggesting the possibility that this species is dispersed throughout the urban area of Foz do Iguaçu. Although so far, no autochthonous cases of VL have been reported in humans and dogs in this city, we recommend the immediate implementation of entomological and epidemiological surveillance, as recommended by the Ministry of Health, $2006^{2}$.

\section{ACKNOWLEDGMENTS}

To the technicians of the Núcleo de Entomologia of Maringá and Foz do Iguacu, for sampling and screening the sandflies; the team members of the Center for Zoonosis Control in the City of Foz do
Iguaçu, for their assistance in field activities; the professionals of the $9^{\text {th }}$ Regional Health Unit of Foz do Iguacu, especially Dr. Eliane Maria Pozzolo, for their support; and Mr. José Dilermano Andrade Filho of the Centro de Referência Nacional e Internacional para Flebotomíneos of the Laboratório de Leishmanioses, Centro de Pesquisas René RachouFundação Oswaldo Cruz, State of Minas Gerais, for confirmation of the species.

\section{CONFLICT OF INTEREST}

The authors declare that there is no conflict of interest.

\section{ABSTRACT IN PORTUGUESE}

\section{O primeiro registro de Lutzomyia longipalpis (Lutz \& Neiva, 1912)} (Diptera: Psychodidae), no Estado do Paraná, Brasil

Introdução: Relata-se pela primeira vez a ocorrência de Lutzomyia longipalpis, no Estado do Paraná, Brasil. Métodos: Os exemplares da espécie foram capturados na área urbana do município de Foz do Iguaçu, com armadilhas luminosas do tipo Falcão, no domicílio e peridomicílio de 61 imóveis residenciais, em duas noites consecutivas, das 18 às 6 horas, em março de 2012. Resultados: Foram capturados 40 exemplares de Lu. longipalpis, juntamente com 54 flebotomíneos de 
outras espécies. Conclusões: Este fato contribui para o conhecimento da área de distribuição geográfica do vetor de Leishamnia chagasi, no Brasil.

Palavras-chaves: Lutzomyia longipalpis. Flebotomíneos. Paraná.

\section{REFERENCES}

1. Young $D$, Duncan M. Guide to the identification and geographic distribution of Lutzomyia sand flies in Mexico, the West Indies, Central and South America (Diptera: Psychodidae). Mem Am Entomol Inst 1994; 54:1-881.

2. Ministério da Saúde. Secretaria de Vigilância em Saúde. Departamento de Vigilância Epidemiológica. Manual de Vigilância e Controle da Leishmaniose Visceral. Brasília: Editora Ministério da Saúde; 2006.

3. Souza GD, Santos E, Andrade Filho JD. The first report of the main vector of visceral leishmaniasis in America, Lutzomyia longipalpis (Lutz \& Neiva) (Diptera: Psychodidae: Phlebotominae), in the state of Rio Grande do Sul, Brazil. Mem Inst Oswaldo Cruz 2009; 104:1181-1182.

4. Pocai EA, Frozza L, Headley AS, Graça DL. Leishmaniose visceral (calazar). Cinco casos em cães de Santa Maria, Rio Grande do Sul, Brasil. Cienc Rur 1998; 28:501-505.

5. Cat I, Luz E, Borba AM, Cassilha A, Costa PB, Martins FL. Leishmaniose visceral autóctone no oeste paranaense. An Fac Med Univ Fed Paraná 1973/1974; 16/17:27-35.

6. Ayala MAR, Bergoxc PM, Anunciação EM. Calazar (primeiro caso autóctone no sudeste do Paraná). J Bras Med 1980; 39:88-89.

7. Salomón OD, Sinagra A, Nevolt MC, Barberian G, Paulin P, Estevez JO, et al. First visceral leishmaniasis focus in Argentina. Mem Inst Oswaldo Cruz 2008; 103:109-111.
8. Salomón OD, Basmajdian Y, Fernández MS, Santini MS. Lutzomyia longipalpis in Uruguay: the first report and the potential of visceral leishmaniasis transmission. Mem Inst Oswaldo Cruz 2011; 106:381-382.

9. Cousiño B. Vigilancia y Control de la Leishmaniasis en el Paraguay. In: Centro Pan-Americano de Febre Aftosa (PANAFTOSA) editors. Consulta de Expertos OPS/OMS sobre Leishmaniasis Visceral em las Américas. Informe final. Rio de Janeiro. Panaftosa/OPS; 2006. p. 34-36. [Internet]. [Cited 2012 April 15]. Available from: http://new.paho.org/hq/index.php?option=com_docman\&task=doc_ view\&gid=16960\&ltemid=.

10. Santini MS, Salomón OD, Acardi SA, Sandoval EA, Tartaglino L. Lutzomyia longipalpis Behavior and control at an urban visceral leishmaniasis focus in Argentina. Rev Inst Med Trop São Paulo 2010; 52:187-191.

11. Salomón OD, Fernández MS, Santini MS, Saavedra S, Montiel N, Ramos MA, et al. Distribution de Lutzomyia longipalpis em la Mesopotamia Argentina, 2010. Med (Buenos Aires) 2011; 71:22-26.

12. Quintana MG, Fernández MS, Salomón OD. Distribuition and Abundance of Phlebotominae, Leishmaniasis, in Argentina: Spatial and Temporal Analysis at Different Scales. J Trop Med 2012; ID 652803:1-16.

13. Silva AM, Camargo NJ, Santos DR, Massafera R, Ferreira AC, Postai C, et al Diversidade, distribuição e abundância de flebotomíneos (Diptera: Psychodidae) no Paraná. Neotrop Entomol 2008; 37:209-225.

14. Prefeitura Municipal de Foz do Iguaçu. Secretaria Municipal da Administração/ Departamento de Informações Institucionais. Dados Socioeconômicos de Foz do Iguaçu-PR. [Internet]. [Cited 2012 April 15]. Available from: http://www.pmfi. pr.gov.br/Portal/VisualizaObjzzzz.aspx?IDObj=12845.

15. Galati EAB. Classificação de Phlebotominae. In: Rangel EF, Lainson R, editors. Flebotomíneos do Brasil. Rio de Janeiro: FIOCRUZ; 2003. p. 23-51. 